\title{
Universally occurring phenylpropanoid and species-specific indolic metabolites in infected and uninfected Arabidopsis thaliana roots and leaves
}

\author{
Jianwen Tan ${ }^{\mathrm{a}, \mathrm{b}}$, Paweł Bednarek ${ }^{\mathrm{a}}$, Jikai Liu $^{\mathrm{b}}$, Bernd Schneider ${ }^{\mathrm{c}}$, Aleš Svatošc \\ Klaus Hahlbrock ${ }^{\mathrm{a}, *}$ \\ ${ }^{a}$ Max-Planck-Institute for Plant Breeding Research, Carl-von-Linne-Weg 10, 50829 Köln, Germany \\ ${ }^{\mathrm{b}}$ Kunming Institute of Botany, Chinese Academy of Sciences, Kunming 650204, China \\ ${ }^{\mathrm{c}}$ Max-Planck-Institute for Chemical Ecology, Beutenberg Campus, Hans-Knöll-Str. 8, 07745 Jena, Germany
}

Received 24 September 2003; received in revised form 21 November 2003

\begin{abstract}
A total of eleven alkali-released, aromatic compounds were identified by HPLC, MS and NMR analyses in cell wall extracts from Arabidopsis thaliana roots. Nine of them together constituted the three complete series of 4-hydroxy-, 4-hydroxy-3-methoxy, and 4hydroxy-3,5-dimethoxy-substituted benzaldehydes, benzoic acids and cinnamic acids. The other two were indolic metabolites: indole-3-carboxylic acid and indole-3-carbaldehyde. Qualitatively similar, but quantitatively distinct profiles were obtained using cell-wall extracts from $A$. thaliana leaves. Several of these compounds, particularly indole-3-carboxylic acid, 4-hydroxybenzoic acid and all four aldehydes, increased considerably in concentration upon infection of roots with Pythium sylvaticum, as did at least some of them upon infection of leaves with Pseudomonas syringae pv tomato. Comparison of these results with analogous data on a variety of different plant species suggests a remarkable structural uniformity among the majority of constitutive as well as infectioninduced, aromatic cell wall-bound compounds throughout the entire plant kingdom - in sharp contrast to the highly speciesspecific, chemically highly divers bouquets of soluble aromatic metabolites.
\end{abstract}

(C) 2004 Elsevier Ltd. All rights reserved.

Keywords: Arabidopsis thaliana; Benzoate derivatives; Cinnamate derivatives; Cell wall-bound compounds; Indole-3-carboxylate; Pseudomonas syringae pv tomato; Pythium sylvaticum

\section{Introduction}

Large changes in secondary metabolism, including the accumulation of phytoalexins and aromatic cell wallbound compounds, are among the earliest detectable results of the extensive transcriptional reprogramming that occurs in challenged plant cells during plant/ pathogen interactions (Somssich and Hahlbrock, 1998; Dixon, 2001; Hahlbrock et al., 2003). Using soluble extracts from Arabidopsis thaliana leaves, we have previously shown that, in addition to the characteristic phytoalexin of this species, camalexin, several other indolic metabolites were strongly and rapidly induced

* Corresponding author. Tel.: +49-221-5062-300; fax: +49-2215062-309.

E-mail address: hahlbroc@mpiz-koeln.mpg.de (K. Hahlbrock). upon infection. By contrast, the only major phenylpropanoid compound besides flavonoids, sinapoyl malate, decreased equally rapidly to very low levels, whereas all of the detectable flavonol glycosides remained largely unaffected (Hagemeier et al., 2001). Comparatively little is known about cell wall-bound substances in uninfected (Franke et al., 2002) and particularly in infected $A$. thaliana leaves, where so far only one indolic compound, indole-3-carboxylic acid, has been shown to accumulate in the cell wall upon compatible or incompatible interactions with a bacterial pathogen (Hagemeier et al., 2001). These findings raised two related questions: What else occurs in the cell wall upon infection, and what are the relative roles of phenylpropanoid and indolic metabolism in the two cellular compartments, particularly in view of the strong activation of biosynthetic genes for both classes of aromatic compounds in infected $A$. 
thaliana tissue (Ehlting et al., 1999; Zhao and Last, 1996).

For methodological reasons, we confined our present studies to alkali-hydrolyzable, UV-absorbing material from crude cell wall preparations, using HPLC conditions under which the two major classes of aromatic (phenylpropanoid and indolic) metabolites are efficiently separated. For simplicity, the term 'phenylpropanoid' will in the following be used collectively for all established and putative phenylalanine-derived compounds, including those benzoic acid and benzaldehyde derivatives whose biosynthetic origin is still ambiguous (Jarvis et al., 2000; Wildermuth et al., 2001; Abd El-Mawla and Beerhues, 2002). Similarly, not all indole derivatives are necessarily derived from one common primary metabolite. For example, tryptophan has been verified as a precursor in several, but notably not in all cases (Tsuji et al., 1993; Normanly and Bartel, 1999).

The long-term aim of these studies is to elucidate the significance of secondary aromatic metabolism in disease resistance and, more specifically, the roles of indolic and phenylpropanoid biosynthetic routes in pathogen defence in plants. However, in all species investigated so far, the bouquet of these compounds, whether constitutively expressed or induced by infection or other kinds of stress, is extremely complex. Moreover, our understanding of this complexity in detail is still so poor and, consequently, the functional assignment of individual components so difficult that more basic knowledge than presently existing has to be gained until such specific questions can be addressed. This applies especially to $A$. thaliana, our species of choice, where little is known about aromatic secondary metabolism, particularly when compared with the extensive and rapidly increasing knowledge about structural and functional details of the genome.

Here, we report the identification of a total of eleven phenylpropanoid and indolic derivatives in the fraction of cell wall-released aromatic compounds, compare the metabolite profiles of $A$. thaliana roots and leaves between uninfected and infected tissues, and discuss the results in relation to those obtained with other plant species.

\section{Results}

\subsection{Choice of tissue}

When these studies were initiated, very little was known about cell wall-bound compounds in $A$. thaliana leaves (Hagemeier et al., 2001), and even less in $A$. thaliana roots. Therefore, we decided to analyze both organs. Because preliminary results had indicated somewhat larger amounts of aromatic cell wall constituents in root than in leaf extracts, we began the analysis with roots.

\subsection{Structural identification of compounds}

Fig. 1A shows a typical HPLC profile of $\mathrm{UV}_{254^{-}}$ absorbing compounds released by alkali from a root cell-wall preparation. All peaks labelled with numbers (1-11) were first provisionally identified by UV spectroscopy and by comparison of the retention times with those of authentic substances. All of the deduced, putative chemical structures (Fig. 1B) were then unequivocally confirmed either by EI-MS in combination with ${ }^{1} \mathrm{H}$ NMR $(1,2,4,5,8)$ or by LC-MS $(3,6,7,9,11)$. Compound 10 had been elucidated previously (Hagemeier et al., 2001). The same set of eleven compounds was observed in an analogous experiment using cell wall extracts from leaves. However, most of them occurred in significantly smaller quantities, and the relative amounts differed considerably and reproducibly between the two types of tissue.

A special case was compound $\mathbf{M}$. It fluctuated greatly in amount from one experiment to another and was highly volatile under the conditions used for preparative analysis. In agreement with this property, $\mathbf{M}$ turned out to be 4-methylbenzaldehyde, again by using MS and

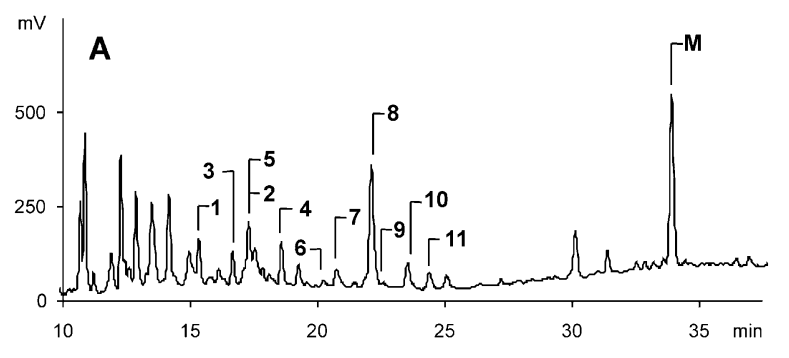

B
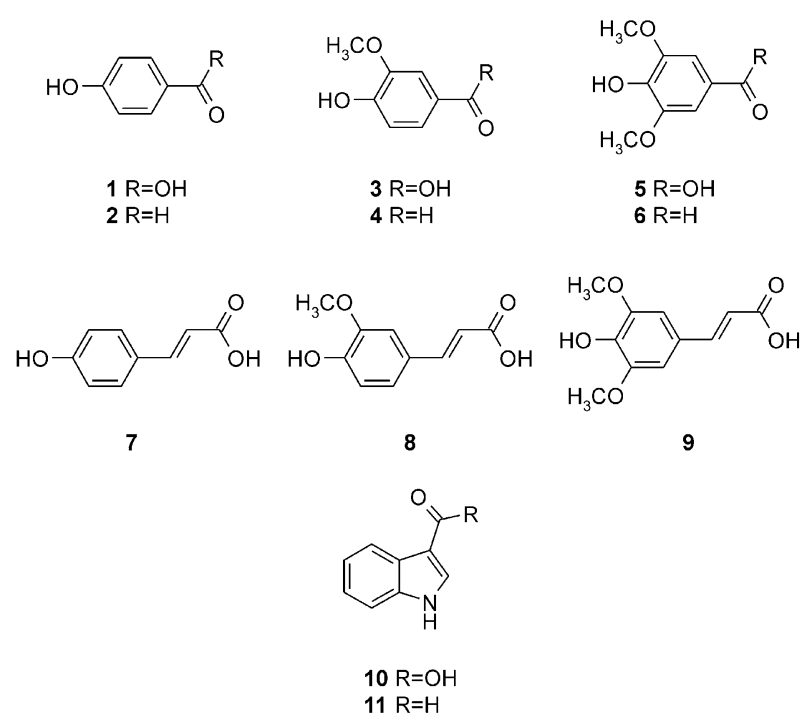

Fig. 1. Alkali-released, aromatic cell wall constituents of $A$. thaliana roots. A: HPLC profile at $254 \mathrm{~nm}$. Chemical structures of compounds 1-11 are given in panel B; see text for special comments on compound M (=4-methylbenzaldehyde). B: Structurally identified 4-hydroxyphenylpropanoid (1-9) and indolic (10,11) cell wall-bound compounds. 
NMR as analytical tools. Accurate mass measurement of protonated $\mathbf{M}$ obtained by positive LC/ESI-MS (found 121.0677, calc. 121.0653 for $\mathrm{C}_{8} \mathrm{H}_{9} \mathrm{O}$ ) revealed the molecular formula $\mathrm{C}_{8} \mathrm{H}_{8} \mathrm{O}$ for the unprotonated form. Commercially available standards fitting this formula were analyzed under comparable conditions, including the generation of daughter spectra at two collision energies (12 and $25 \mathrm{eV}$ ). Only 4-methylbenzaldehyde showed a UV spectrum, a retention time and MS/MS spectra that were identical with those of $\mathbf{M}$. The identity was further confirmed by ${ }^{1} \mathrm{H}$ NMR spectra. It remains open at this stage of analysis whether $\mathbf{M}$ is an artefact or a bona fide natural product.

\subsection{Accumulation in infected tissue}

The majority of compounds $\mathbf{1}-\mathbf{1 1}$ increased more or less strongly during infections of $A$. thaliana roots with the pathogenic oomycete, Pythium sylvaticum (Psy), as shown in Fig. 2 for the 72-h time point postinoculation. Most strongly induced were compounds 1 and 10, but at least 2, 4, 6 and 11 were also induced, albeit to lesser extents. By contrast, several of the unidentified compounds with retention times below that of $\mathbf{1}$ decreased significantly, whereas the constitutively abundant compounds $\mathbf{5}$ and $\mathbf{8}$ remained unchanged within experimental error.

Much more moderate were the changes occurring in leaves infected with the bacterial pathogen Pseudomonas syringae pv tomato (Pst, Fig. 3), except that the only previously identified, Pst-induced cell-wall constituent, compound 10 (Hagemeier et al., 2001), again accumulated to high levels (Fig. 3B), though from a higher background (Fig. 3A) than that noted in roots (Fig. 2A). Also in contrast to roots, no significant changes were detectable at retention times below that of compound $\mathbf{1}$. Besides 10, the most strongly induced compounds were
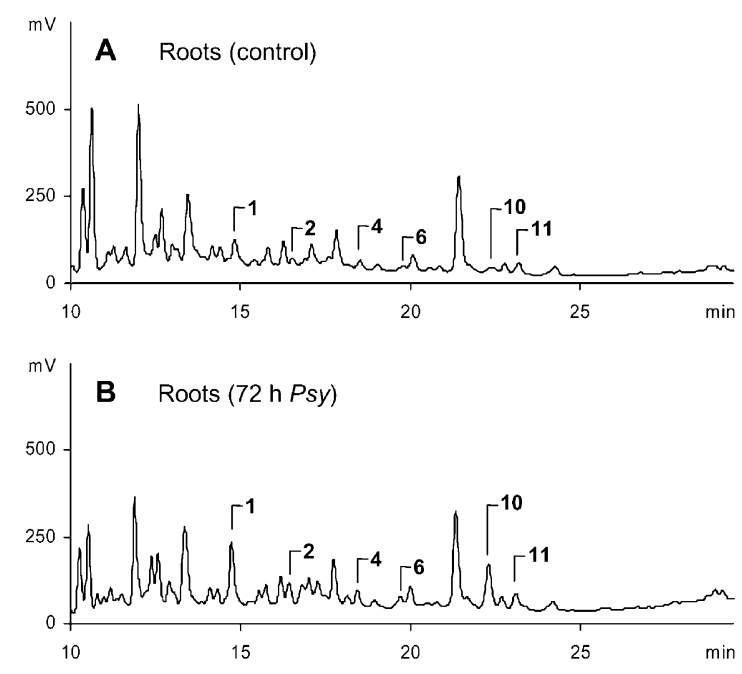

Fig. 2. HPLC profiles of cell wall-released aromatic compounds (A) from uninfected $A$. thaliana roots and (B) from roots $72 \mathrm{~h}$ postinoculation with Pythium sylvaticum (Psy).
1 and 11. Additional changes are quite possible, but would be too small to be verified unequivocally under the conditions used.

According to previous results, $\mathbf{1 0}$ accumulates to more than two-fold higher levels in incompatible than in compatible $P s t / A$. thaliana leaf interactions (Hagemeier et al., 2001). In extension of this data, we now also determined the accumulation kinetics of the two less strongly, but likewise unequivocally accumulating compounds, 1 and 11, in cell-wall extracts from $P$ st-infected $A$. thaliana leaves, using $\mathbf{1 0}$ as reference (Fig. 4). Similar to 10, both 1 and 11 began to increase about $12 \mathrm{~h}$ postinoculation and reached maximal levels at about $60 \mathrm{~h}$ in the incompatible interaction. In the compatible interaction, the increase was delayed in all three cases, and the maximally reached values were significantly lower.

\subsection{Comparison with cultured parsley cells}

For comparison of $A$. thaliana with a plant species lacking indolic derivatives among the infection-induced, aromatic metabolites (Hagemeier et al., 1999), we performed an analogous analysis of cell wall-bound compounds in elicitor-treated, cultured parsley cells (Petroselinum crispum), employing the same hydrolysis, extraction and HPLC conditions as used above. Based on the results obtained with $A$. thaliana, peaks were assigned (Fig. 5) by comparison of UV spectra and retention times with those of authentic substances. Following treatment of control cells (Fig. 5A) with a pathogen-derived elicitor (Fig. 5B), six of the nine benzoate (1-4) and cinnamate $(\mathbf{7}, \mathbf{8})$ derivatives identified above as cell wall-bound compounds in A. thaliana were both constitutively present in P. crispum cells and
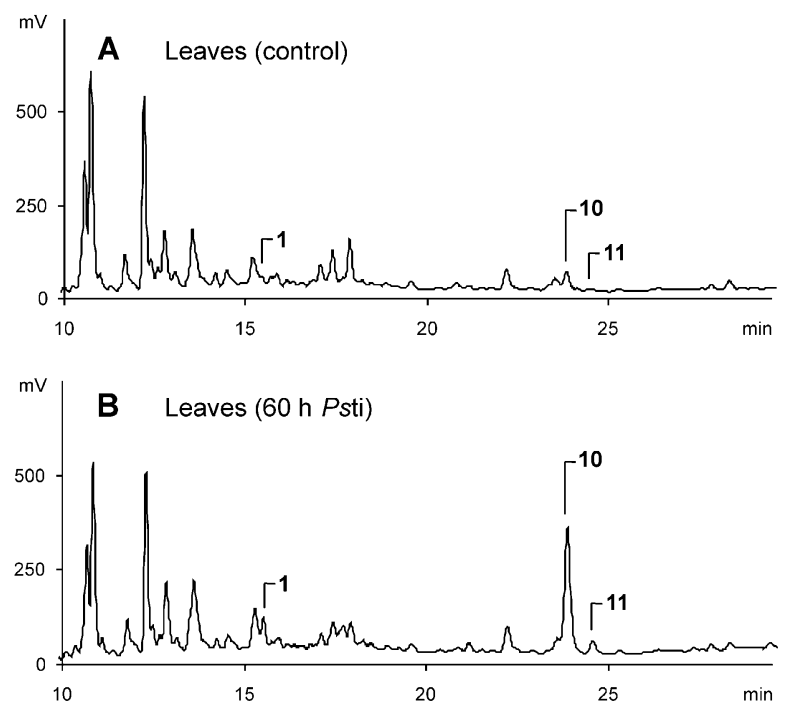

Fig. 3. HPLC profiles of cell wall-released aromatic compounds (A) from uninfected $A$. thaliana leaves and (B) from leaves $60 \mathrm{~h}$ postinoculation with an avirulent strain of Pseudomonas syringae pv tomato causing an incompatible interaction (Psti). 

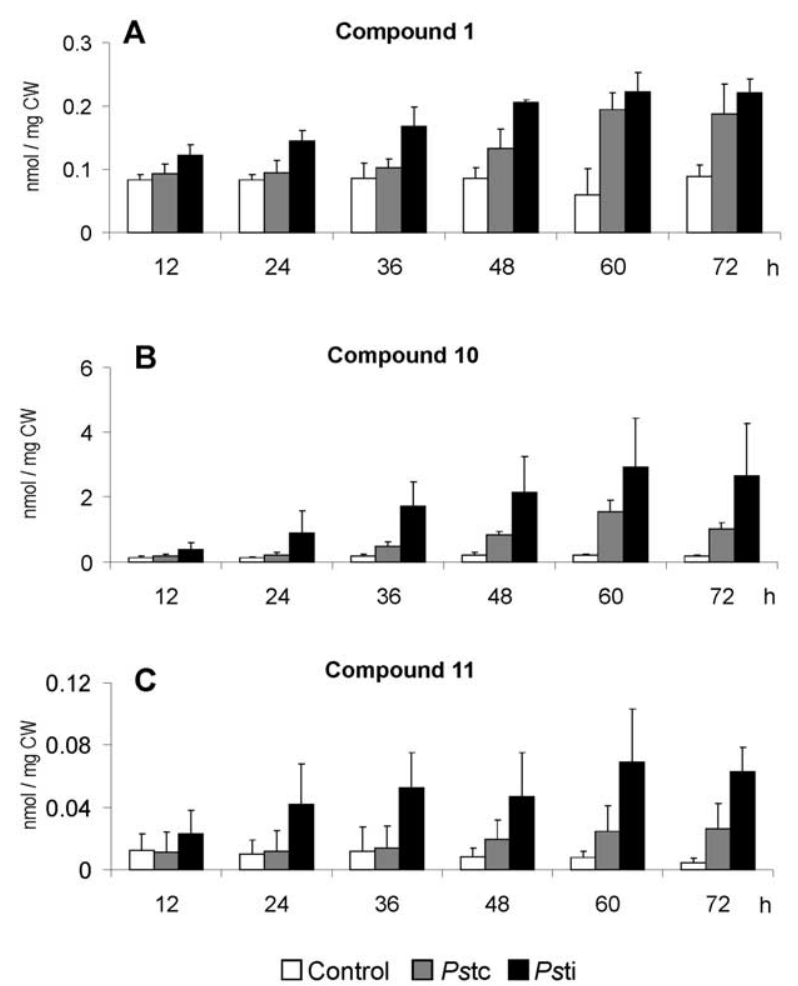

Fig. 4. Quantitative estimation of infection-induced increases in three of the most prominent cell wall-bound compounds from $A$. thaliana leaves at the indicated times post inoculation. $P$ stc $=$ compatible interaction with Pseudomonas syringae pv tomato; Psti=incompatible interaction with $P$. syringae pv tomato; $\mathrm{CW}=$ cell wall preparation. Bars indicate maximal deviations from mean values derived from 3 independent measurements each (for structures see Fig. 1).

strongly elevated upon elicitor treatment. As in $A$. thaliana roots (Fig. 2) and leaves (Fig. 3), 4-hydroxybenzoic acid (1) was one of the most strongly induced phenylpropanoid derivatives in elicited $P$. crispum cells.

\section{Discussion}

Together with the results of our preceding study (Hagemeier et al., 2001), these data indicate a distinctive difference between soluble and cell wall-associated, aromatic secondary metabolism in infected $A$. thaliana tissues. While some of the most prominent phenylpropanoid metabolites decreased rapidly and strongly in the soluble fraction of infected $A$. thaliana leaves (Hagemeier et al., 2001) or roots (P. Bednarek, unpublished results), several cell wall-bound phenylpropanoids increased with similar timing. Except for the two closely related indolic metabolites (10 and 11), all of the aromatic cell wall-bound compounds identified so far in A. thaliana are benzoate $(\mathbf{1}, \mathbf{3}, \mathbf{5})$, benzaldehyde $(\mathbf{2}, \mathbf{4}, \mathbf{6})$ or cinnamate (7-9) derivatives, that is, phenylpropanoids. This latter group of nine likewise structurally related compounds constitutes three analogous series of
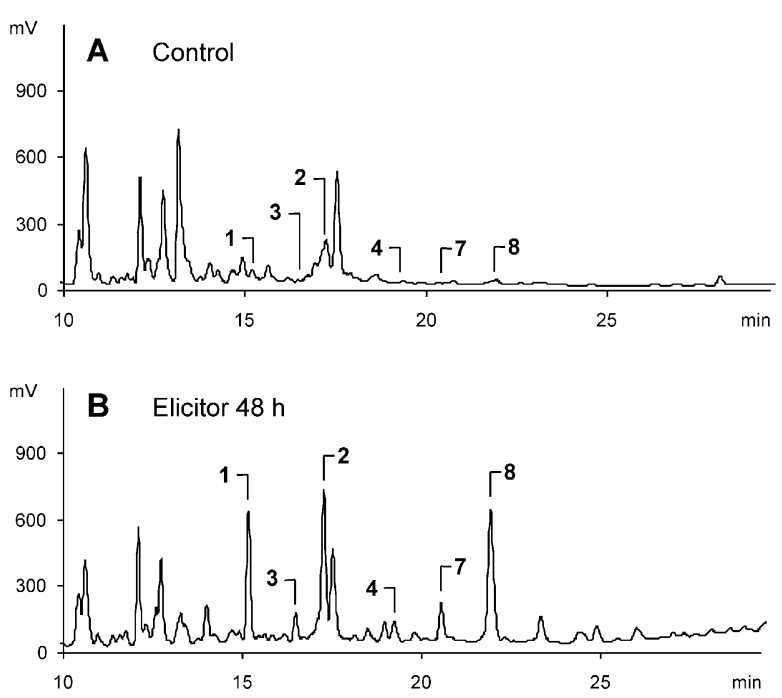

Fig. 5. HPLC profiles of cell wall-released aromatic compounds (A) from untreated and (B) from elicitor-treated, suspension-cultured Petroselinum crispum cells.

4-hydroxylated phenylpropanoids bearing either none, one or two additional ortho-methoxy groups. It is precisely these substitution patterns that have most frequently been observed for various kinds of plant cell wall-associated phenolics, including the three characteristic 4-hydroxyphenyl, guaiacyl and syringyl building blocks of lignin (Dixon et al., 2001; Humphreys and Chapple, 2002). Notably, none of the three corresponding cinnamaldehyde derivatives were detected, neither in A. thaliana nor in P. crispum, although the complete, analogous benzaldehyde series was present in $A$. thaliana roots, and although one member of the cinnamic acid series $(\mathbf{8})$ was even among the most abundant aromatic cell wall-bound compounds (Fig. 1).

Remarkably, all cell wall-bound compounds that accumulated to significantly elevated levels upon infection or elicitor treatment were also constitutively present in more or less sizable amounts, in roots and in leaves of $A$. thaliana as well as in cultured $P$. crispum cells. This result is particularly well documented by the data obtained for $A$. thaliana roots and $P$. crispum cells, whereas the analogous metabolite profiles for $A$. thaliana leaves were less pronounced. However, all sufficiently clear-cut data indicate not only the structural identity of preformed and infection- or elicitor-induced cell-wall constituents, but also the far-reaching similarity in this regard between $A$. thaliana leaves and roots.

Although an extensive literature exists on numerous soluble, aromatic secondary metabolites that have been functionally associated with disease resistance in plants (Dixon, 2001, and references cited therein), comparatively little is known about their wall-bound counterparts. Similar to our present study, a variety of mono- and dicotyledonous plants or plant cell cultures have been analyzed with regard to infection- or elicitor-induced, 
alkali-labile, aromatic cell wall-bound compounds, including Lycopersicon esculentum (Beimen et al., 1992), Medicago sativa (Cvikrova et al., 1993), Solanum tuberosum (Keller et al., 1996), Petroselinum crispum (Kauss et al., 1993; Franke et al., 1998), Phoenix dactylifera (El Modafar et al., 2000) and Musa acuminata (De Ascensao and Dubery, 2003). In all cases, moderately or even strongly elevated levels of some or most of the nine phenylpropanoid derivatives identified here were observed, with the three corresponding cinnamaldehydes again lacking without exception. However, the functional significance of these findings has remained elusive. Nevertheless, our present data on A. thaliana, as well as those (Fig. 5) extending earlier studies on cultured P. crispum cells (Kauss et al., 1993; Franke et al., 1998), are in full accord with, and further confirm, the general conclusion (Hahlbrock et al., 2003) that the three analogous series of 4-hydroxy-, 4-hydroxy-3-methoxy-, and 4-hydroxy-3,5-dimethoxybenzaldehyde, -benzoate and -cinnamate together constitute a characteristic set of universally occurring, aromatic cell wall-bound compounds in higher plants.

Whether this set comprises these nine or more structurally and/or biosynthetically related phenylpropanoids is difficult to decide solely on the basis of their frequency of detection. The occasional, additional detection of caffeic ( $3^{\prime}, 4^{\prime}$-dihydroxycinnamic) acid among the alkalireleased cell-wall constituents (Beimen et al., 1992) may indicate that some or all of the corresponding 3,4-dihydroxy-substituted compounds are either true or at least optional members of the respective series. Their rare detection could readily be explained either by exceptionally high losses of the oxidation-prone ortho-dihydroxy intermediates during extraction and purification, by particularly high metabolic conversion (methylation) rates, or by a combination of both. Therefore, as well as in view of its role as an essential intermediate in the biosynthesis of the $3^{\prime}$ - and $3^{\prime}, 5^{\prime}$-methoxylated $4^{\prime}$-hydroxycinnamates (Dixon et al., 2001; Humphreys and Chapple, 2002), we consider at least caffeic acid to be a true, but easily overlooked, member of the universal set of plant cell wall-bound compounds. As the biosynthetic pathways leading to the various benzoic acid and benzaldehyde derivatives are less clearly defined, it remains open whether the same applies to these two series, and hence, whether the total set comprises the minimal number of nine, the more likely number of at least ten, or even eleven or more members.

In contrast to the nine (or more) universally occurring phenylpropanoid derivatives, the two indolic compounds, 10 and 11, have not been detected in the cell wall of any plant species other than A. thaliana. Their highly species-specific occurrence in this compartment may be taken as a valuable clue towards an understanding of the role of the cell wall in A. thaliana secondary metabolism. Although neither $\mathbf{1 0}$ nor $\mathbf{1 1}$ were detected in soluble extracts from uninfected leaves (Hagemeier et al., 2001), 10 was present in analogous extracts from roots (P. Bednarek, unpublished results). This, together with the low but clear-cut presence of both $\mathbf{1 0}$ and $\mathbf{1 1}$ in cell-wall extracts from uninfected roots as well as leaves, implies at least low constitutive levels of the respective biosynthetic activities, which in turn suggests that infection triggers increases in pre-existing accumulation rates, rather than inducing previously silent pathways anew. The strong, concomitant accumulation of $\mathbf{1 0}$ as glucose ester in the soluble fraction (Hagemeier et al., 2001) and as an alkali-released compound in the cell wall fraction further suggests that the soluble and cell wall compartments are metabolically closely interconnected, possibly to the extent that the acyl moieties of soluble and cell-wall conjugates are readily exchangeable.

This latter notion most likely applies to the wall-bound benzoate and cinnamate derivatives as well. All of them are also among the most frequently occurring soluble conjugates in numerous plant species. A prominent member of this group is sinapoylmalate, one of the most abundant, soluble aromatic metabolites in untreated $A$. thaliana leaves, which declines rapidly, however, upon infection (Hagemeier et al., 2001). This strong decline, together with the lack of an infection-induced increase of its wall-bound counterpart (9)-similar to the other two wall-bound cinnamate derivatives ( $\mathbf{7}$ and $\mathbf{8})$, but in contrast to most of the benzoate/benzaldehyde derivatives (1, 2, 4 and 6) - suggests a metabolic involvement of the three cinnamate residues (7-9) outside the presently investigated realms. The striking identity of their substitution patterns with those of the three characteristic lignin building blocks seems to indicate their direct or indirect involvement in the formation of lignin or of the less clearly defined 'lignin-like material', both of which have frequently been postulated to be re-enforced or newly formed as physical barriers around pathogen infection sites (Tiburzy and Reisener, 1990; Kovats et al., 1991; Bennett et al., 1996). Such a role of compounds 7-9 in lignin-related metabolism would readily explain not only their apparent lack of accumulation upon infection, but also the absence of detectable amounts of the corresponding aldehydes. These aldehydes, apart from being chemically unstable and therefore easily lost during extraction, are even more immediate lignin precursors and might rapidly be convertedpossibly in compartmentalized form by metabolic channelling - to the respective monolignols and their polymerization products (Dixon et al., 2001; Humphrey and Chapple, 2002). However, how close these considerations are to reality can not be decided without precise turnover measurements and the elucidation of individual precursor-product relationships within the entire metabolic grid. For example, one probable extension of the outlined metabolic connections may be associated with the additional, quantitatively unresolved 
role of ferulic acid (8) as a substrate for cell wall crosslinking through dimerization of ferulate residues (Fry, 1986; Iiyama et al., 1994; Obel et al., 2003).

Even less obvious are the functional options for the corresponding benzoate and benzaldehyde series. Although both cell wall and soluble benzoate conjugates have been described as frequently as those of the analogous cinnamate derivatives, convincing clues as to their physiological roles, particularly in pathogen defence, are still lacking. One frequent suggestion has been their contribution to the rigidity, impenetrability and hydrophobicity of the cell wall, but to our knowledge, clear-cut evidence has not been provided. Also unresolved, for all compounds described here, is the nature of the chemical bonding to the cell wall. While the majority of alkali-hydrolyzable benzoate and cinnamate derivatives are likely to be linked to the cell wall via ester or amide bonds (Keller et al., 1996), the situation is even more equivocal for the aldehydes.

Despite the overwhelming predominance of phenylpropanoid derivatives in A. thaliana cell-wall extracts, the infection-induced increases, particularly in leaves, were considerably larger for the two indolic metabolites, $\mathbf{1 0}$ and 11, than even for the most strongly responding phenylpropanoid compound, $\mathbf{1}$ (Fig. 3). For 10, this increase is paralleled by a similarly strong, possibly somewhat more rapid induction of its glucose ester in soluble leaf extracts (Hagemeier et al., 2001), suggesting a close biosynthetic relationship (see above). We have previously speculated that the accumulating cell wall-bound indole-3-carboxylate (10) represents one of the induced end products of pathogen defence-related indolic metabolism (Hagemeier et al., 2001), with the indolic phytoalexin, camalexin (Tsuji et al., 1992), and the indolic glucosinolates (Brader et al., 2001) being the major soluble counterparts. However, the precise role in pathogen defence, as well as the nature of the chemical bonding to the cell wall, have yet to be elucidated for both $\mathbf{1 0}$ and $\mathbf{1 1}$.

In conclusion, this study provides new insights into the extent to which the cell wall is involved in aromatic secondary metabolism and, in this context, in pathogen defence in A. thaliana. At the same time, however, it clearly demonstrates that much further work is needed to unravel the complex interplay between the operationally so-defined, but metabolically poorly resolved, 'soluble' and 'cell wall' compartments, and to elucidate the actual mechanisms of pathogen defence at the biochemical level.

\section{Experimental}

\subsection{Plant material}

Liquid root cultures of $A$. thaliana, ecotype Col-0, were initiated as described by Reintanz et al. (2001) with some minor modifications and were grown at $20{ }^{\circ} \mathrm{C}$ under 12-h light periods for 4 weeks. Plants of the same ecotype were grown under 16-h light periods for 5 weeks at $22{ }^{\circ} \mathrm{C}$. Parsley (Petroselinum crispum) cells were propagated as described (Kombrink and Hahlbrock, 1986).

\subsection{Infections and elicitor treatment}

Pythium sylvaticum strain DSM 2322 (Deutsche Sammlung von Mikroorganismen und Zellkulturen, Braunschweig, Germany) was grown on Potato Dextrose Agar plates (Becton Dickinson Microbiology Systems, Sparks, USA) for 1 week. Single pieces of agar with mycelium $(\sim 2 \mathrm{~mm} \times 2 \mathrm{~mm})$ were transferred to the root culture medium. After $72 \mathrm{~h}$, infected and sterilegrown control roots ( $\sim 5 \mathrm{~g}$ each) were collected. Pseudomonas syringae pathovar tomato, strain DC3000 or strain DC3000 carrying the avirulence gene avrRpml, were grown, infiltrated into $A$. thaliana leaves, and leaf samples $(\sim 2.5 \mathrm{~g})$ were collected as described by Hagemeier et al. (2001). Parsley cells were treated with Pep25 elicitor (Nürnberger et al., 1994) at a concentration of $0.3 \mu \mathrm{g} \mathrm{ml} \mathrm{m}^{-1}$ and collected $48 \mathrm{~h}$ after elicitation. Immediately after collection, samples were frozen in liquid $\mathrm{N}_{2}$ and stored at $-80{ }^{\circ} \mathrm{C}$.

\subsection{Extraction procedure and HPLC analysis}

Frozen material was homogenized with an UltraTurrax homogenizer (IKA, Staufen, Germany) in 50\% aq. $\mathrm{MeOH}(20 \mathrm{ml})$, shaken at room temp. for $15 \mathrm{~min}$ and centrifuged for $15 \mathrm{~min}$ at $4000 \mathrm{~g}$. The supernatant was removed and the residues were washed sequentially with the following solutions: $\mathrm{MeOH}, \mathrm{H}_{2} \mathrm{O}, 0.5 \%$ SDS, 1 $\mathrm{M} \mathrm{NaCl}, \mathrm{H}_{2} \mathrm{O}, \mathrm{MeOH}, \mathrm{Me}_{2} \mathrm{CO}$ and $n$-hexane $(2 \times 25 \mathrm{ml}$ each, shaken and centrifuged as above). The residues were operationally defined as purified cell walls and stored at $-20{ }^{\circ} \mathrm{C}$ after drying at $40{ }^{\circ} \mathrm{C}$ in a Speed-Vac (Eppendorf, Hamburg, Germany). For hydrolysis, cell walls $(25 \mathrm{mg} / \mathrm{sample})$ were transferred to screw-cap vials, suspended under $\mathrm{N}_{2}$ in $3 \mathrm{ml}$ of $1 \mathrm{M} \mathrm{NaOH}$ and incubated in darkness for $24 \mathrm{~h}$ at $80^{\circ} \mathrm{C}$. Reaction mixtures were then acidified to $\mathrm{pH}=3$ with concentrated $\mathrm{HCl}$ and extracted 3 times with ethyl acetate (1:1, vol/vol). Appropriate organic fractions were combined and evaporated to dryness at $30{ }^{\circ} \mathrm{C}$ with a Speed-Vac. Residues were re-dissolved in $100 \mu \mathrm{l}$ of $80 \%$ aq. $\mathrm{MeOH}$. Samples $(20 \mu 1)$ were subjected to HPLC on a Nucleosil C-18 column (EC 250/4, 120-5; Macherey \& Nagel), with $0.1 \%$ TFA as solvent $\mathrm{A}$ and $98 \%$ acetonitrile $/ 0.1 \%$ TFA as solvent B, at a flow rate of $1 \mathrm{ml} \mathrm{min}-1$ at $24{ }^{\circ} \mathrm{C}$ (gradient of solvent A: $100 \%$ at $0,94 \%$ at $3,80 \%$ at 13 , $76 \%$ at $20,37 \%$ at $44,0 \%$ at $46 \mathrm{~min}$ ), using a Photodiode Array Detector 540 at $254 \mathrm{~nm}$ as part of the Biotech System (Solvent Delivery System 522, Autosampler 565, Jet-Stream plus, Degasy DG 1210, software CHROMA 
2000; Biotech, Neufahrn, Germany). For prep. HPLC, a Nucleosil C-18 SP 250/10 120-5 column and the respective part of the gradient were used under otherwise identical conditions.

\subsection{Chemicals}

Isomers of methylbenzaldehyde (2-, 3-, and 4-), phytane, 2,3-dihydro- $2 H$-benzofurane, acetophenone, phenylacetaldehyde, formic acid, and 4-hydroxy-[E]-cinnamic acid were obtained from Aldrich (Milwaukee, USA). 4Hydroxy-3,5-dimethoxybenzoic acid was from Merck (Darmstadt, Germany), and indole-3-carbaldehyde was from Fluka (Buchs, Switzerland). All standards were used without further purification. Acetonitrile of HPLC grade was from Fischer Scientific (Loughborough, UK).

\subsection{Mass spectrometry and LC-MS}

Electron impact mass spectra (EI-MS) were recorded using a VG Autospec 3000 mass spectrometer (VG, Manchester, England). Ionization was achieved at $70 \mathrm{eV}$ electron energy and samples were introduced with a direct insertion probe (DIP).

\subsection{1. $L C-M S$}

Samples were analyzed by ESI-MS using a HewlettPackard (Avondale, PA, USA) HP 1100 HPLC coupled to a Micromass Quattro II (Micromass, Manchester, UK) tandem quadrupole mass spectrometer (geometry quadrupole-hexapole-quadrupole) equipped with an electrospray ionization (ESI) source. The capillary and cone voltages in ESI mode were $3.3 \mathrm{kV}$ and $18 \mathrm{~V}$, respectively. $\mathrm{N}_{2}$ was used for nebulization $\left(151 \mathrm{~h}^{-1}\right)$ and as drying gas $\left(250 \mathrm{l} \mathrm{h}^{-1}\right)$. Source and capillary were heated at $80{ }^{\circ} \mathrm{C}$ and $250{ }^{\circ} \mathrm{C}$, respectively. The mass spectrometer was operated in conventional scanning mode using the first quadrupole. Negative-ion and positive-ion full-scan mass spectra were recorded over the range of $m / z 90-450$ at a scanning time of 1.5 seconds. Fixed precursor ion (MS/MS) spectra (a daughter ion scan) were recorded by setting the first quadrupole to transmit the parent ion of interest and scanning the product ions obtained after collision of parent ions in the hexapole gas cell using the second quadrupole analyser. Fixed product spectra (a parent ion scan) were recorded by setting the second quadrupole to transmit the daughter ion of interest. Argon was used for collisioninduced dissociations at $1.5 \times 10^{-3} \mathrm{mbar}$ and the collision energy was varied from 12 to $50 \mathrm{eV}$ for fragmentation. Separation of compounds was achieved on a reverse phase column $(5 \mu \mathrm{m} \mathrm{C18}$ phase, $250 \times 2.1 \mathrm{~mm}$ i.d., Supelco) equipped with a precolumn (Supelco). The solvent system was $\mathrm{H}_{2} \mathrm{O}$ with $0.1 \% \mathrm{HCO}_{2} \mathrm{H}(\mathrm{A})$ or acetonitrile (B). The following gradient was used: $0-6 \mathrm{~min}$, $2-4 \%$ of $\mathrm{B} ; 6-13 \mathrm{~min} 4-18 \%$ of $\mathrm{B} ; 13-17 \mathrm{~min}, 18-28 \%$ of
B; $17-22 \min , 28-53 \%$ of $\mathrm{B} ; 22-24 \mathrm{~min}, 53-93 \%$ of $\mathrm{B}$ and $24-29 \mathrm{~min}$, hold $93 \%$ of $\mathrm{B}$. The flow was maintained at $0.4 \mathrm{ml} \mathrm{min}{ }^{-1}$ and the column temperature was set at $30{ }^{\circ} \mathrm{C}$. Effluent pass through serially connected UV detector set at 230 or $280 \mathrm{~nm}$ before splitting to a waste and to the API source (flow ca $30 \mu 1 \mathrm{~min}^{-1}$ ).

Accurate mass measurement was performed in LCMS mode using a PEEK mixing TEE with a small mixing chamber (Ziemer Chromatographie, Langerwehe, Germany), where one arm was connected to split HPLC column effluent (reduced to ca $30 \mu \mathrm{min}^{-1}$ ), and the other arm to a syringe pump (Harvard apparatus, Matick, MA) delivering a solution of polyethylene glycole oligomers (PEG; average $\mathrm{M}_{\mathrm{r}} 300 \mathrm{Da}$; Aldrich, ca $1 \mathrm{mg}$ $\mathrm{ml}^{-1}$ dissolved in MeOH:1 mM ammonium acetate; $1 / 1$ ) at a flow rate of $7 \mu 1 \mathrm{~min}^{-1}$. Scans were measured in full mass mode from 85 to $200 \mathrm{Da}$ at $5 \mathrm{~s} / \mathrm{scan}$ in a continuum mode and the data were collected in 128 data point mode. The measured scans were internally calibrated using PEG $[\mathrm{M}+\mathrm{H}]^{+},\left[\mathrm{M}+\mathrm{NH}_{4}\right]^{+}$and $[\mathrm{M}+\mathrm{Na}]^{+}$ion masses.

\subsection{NMR spectroscopy}

${ }^{1} \mathrm{H}$ NMR spectra were recorded on a Avance DRX 500 NMR spectrometer (Bruker, Karlsruhe, Germany). Chemical shift values $(\delta)$ are given relative to TMS as an internal standard, coupling constants in $(\mathrm{Hz})$. Compound $\mathbf{M}$ was extracted from the sample $\left(\mathrm{H}_{2} \mathrm{O} / \mathrm{MeOH}\right.$ solution) with $n$-pentane- $d_{12}$ and the ${ }^{1} \mathrm{H}$ NMR and long-range COSY spectra of the extract were immediately measured using a $5 \mathrm{~mm}$ TXI CryoProbe ${ }^{\mathrm{TM}}$.

\subsection{Spectral data of cell wall-bound compounds}

4.7.1. 4-Hydroxybenzoic acid (1)

${ }^{1} \mathrm{H}$ NMR $\left(\mathrm{CD}_{3} \mathrm{OD}\right) \delta 7.86(2 \mathrm{H}, d, J=8.6 \mathrm{~Hz}, 2-\mathrm{H}$ and 6-H), $6.80(2 \mathrm{H}, d, J=8.6 \mathrm{~Hz}, 3-\mathrm{H}$ and 5-H). EI-MS $m / z$ (rel. int.) $138[\mathrm{M}]^{+}$. (77), $121\left[\mathrm{M}-\mathrm{OH}^{\bullet}\right](100), 93[\mathrm{M}-$ $\mathrm{COOH}](20), 65\left[\mathrm{C}_{5} \mathrm{H}_{5}\right]$ (34).

\subsubsection{4-Hydroxybenzaldehyde (2)}

${ }^{1} \mathrm{H}$ NMR $\left(\mathrm{CD}_{3} \mathrm{OD}\right) \delta 9.76(1 \mathrm{H}, s,-\mathrm{C} \underline{\mathrm{HO}}), 7.77(2 \mathrm{H}, d$, $J=8.6 \mathrm{~Hz}, 2-\mathrm{H}$ and $6-\mathrm{H}), 6.91(2 \mathrm{H}, \bar{d}, J=8.6 \mathrm{~Hz}, 3-\mathrm{H}$ and 5-H). EI-MS $m / z$ (rel. int.) $122[\mathrm{M}]^{+} \cdot(90), 121[\mathrm{M}-$ $\mathrm{H}](100), 93[\mathrm{M}-\mathrm{H}-\mathrm{CO}](34), 65\left[\mathrm{C}_{5} \mathrm{H}_{5}\right]$ (45).

\subsubsection{4-Hydroxy-3-methoxybenzoic acid (vanillic acid, 3)}

ESI-MS $m / z$ (rel. int.) $169[\mathrm{M}+\mathrm{H}]^{+}$, daughter spectrum $(20 \mathrm{eV}) 169(5), 151\left[\mathrm{M}+\mathrm{H}-\mathrm{H}_{2} \mathrm{O}\right](25), 123$ (30), $110(18), 93\left[\mathrm{C}_{6} \mathrm{H}_{5} \mathrm{O}\right](100), 81(8), 65\left[\mathrm{C}_{5} \mathrm{H}_{5}\right](60)$.

\subsubsection{4-Hydroxy-3-methoxybenzaldehyde (vanillin, 4)}

${ }^{1} \mathrm{H}$ NMR $\left(\mathrm{CD}_{3} \mathrm{OD}\right) \delta 9.74(1 \mathrm{H}, s,-\mathrm{CHO}), 7.43(1 \mathrm{H}$, $b s, 2-\mathrm{H}), 7.42(1 \mathrm{H}, b d, J=7.9 \mathrm{~Hz}, 6-\mathrm{H}), 6.93(1 \mathrm{H}, d$, $J=7.9 \mathrm{~Hz}, 5-\mathrm{H}), 3.91\left(3 \mathrm{H}, s, 3-\mathrm{OCH}_{3}\right)$. EI-MS $m / z$ (rel. 
int.) $152[\mathrm{M}]^{+} \cdot(100), 151[\mathrm{M}-\mathrm{H}](80), 137[\mathrm{M}-\mathrm{H}-\mathrm{CO}]$ (6), 123 (13), $109\left[\mathrm{C}_{6} \mathrm{H}_{5} \mathrm{O}_{2}\right](20), 81$ (27), $65\left[\mathrm{C}_{5} \mathrm{H}_{5}\right]$ (7).

\subsubsection{4-Hydroxy-3,5-dimethoxybenzoic acid (syringic} acid, 5)

${ }^{1} \mathrm{H}$ NMR $\left(\mathrm{CD}_{3} \mathrm{OD}\right) \delta 7.32(2 \mathrm{H}, s, 2-\mathrm{H}, 6-\mathrm{H}), 3.84$ $\left(6 \mathrm{H}, s, 3-\mathrm{OCH}_{3}, 5-\mathrm{OCH}_{3}\right)$. HR-EIMS $m / z 198.052824$ $\left(\mathrm{C}_{9} \mathrm{H}_{10} \mathrm{O}_{5}\right.$, calc. 198.051659). EI-MS $m / z$ (rel. int.) 198 $[\mathrm{M}]^{+} \cdot(100), 183\left[\mathrm{M}-\mathrm{CH}_{3}^{*}\right](32), 167\left[\mathrm{M}-\mathrm{CH}_{3} \mathrm{O} \bullet\right](21)$, 155 (18), 137 (7), 127 (25), 109 (16), 79 (11).

\subsubsection{4-Hydroxy-3,5-dimethoxybenzaldehyde (syringaldehyde, 6 )}

ESI-MS $m / z$ (rel. int.) $183[\mathrm{M}+\mathrm{H}]^{+}$, daughter spectrum $(20 \mathrm{eV}) 183(2), 155\left[\mathrm{M}+\mathrm{H}-\mathrm{H}_{2} \mathrm{O}\right](10), 140$ (70), 123 (75), 95 (100), 77 [ $\left.\mathrm{C}_{6} \mathrm{H}_{5}\right](95), 67$ (15).

\subsubsection{4-Hydroxy-(E)-cinnamic acid [(E)-4-coumaric acid, 7$]$}

ESI-MS $m / z$ (rel. int.) $165[\mathrm{M}+\mathrm{H}]^{+}$, daughter spectrum $(20 \mathrm{eV}) 165(31), 147\left[\mathrm{M}+\mathrm{H}-\mathrm{H}_{2} \mathrm{O}\right](10), 119$ (30), $101(5), 91\left[\mathrm{C}_{7} \mathrm{H}_{7}\right](100), 65\left[\mathrm{C}_{5} \mathrm{H}_{5}\right](15)$.

\subsubsection{4-Hydroxy-3-methoxy-(E)-cinnamic acid [(E)-ferulic acid, 8 ]}

${ }^{1} \mathrm{H}$ NMR $\left(\mathrm{CD}_{3} \mathrm{OD}\right) \delta 7.59(1 \mathrm{H}, d, J=16.0 \mathrm{~Hz}, \beta-\mathrm{H})$, $7.18(2 \mathrm{H}, d, J=2.0 \mathrm{~Hz}, 2-\mathrm{H}), 7.06(2 \mathrm{H}, d d, J=8.1,2.0$ $\mathrm{Hz}, 6-\mathrm{H}), 6.80(1 \mathrm{H}, d, J=8.1 \mathrm{~Hz}, 5-\mathrm{H}), 6.30(1 \mathrm{H}, d$, $J=16.0 \mathrm{~Hz}, \alpha-\mathrm{H}), 3.89\left(1 \mathrm{H}, s, 3-\mathrm{OCH}_{3}\right)$. EI-MS $m / z$ (rel. int.): $194[\mathrm{M}]^{+} \cdot(100), 177\left[\mathrm{M}-\mathrm{OH}^{\bullet}\right](8), 133$ (17), $107\left[\mathrm{C}_{7} \mathrm{H}_{7} \mathrm{O}\right](22), 91\left[\mathrm{C}_{7} \mathrm{H}_{7}\right](15)$.

\subsubsection{4-Hydroxy-3,5-dimethoxy-(E)-cinnamic acid [(E)-sinapic acid, 9]}

ESI-MS $m / z$ (rel. int.) $225[\mathrm{M}+\mathrm{H}]^{+}$, daughter spectrum $(20 \mathrm{eV}) 225$ (1), $207\left[\mathrm{M}+\mathrm{H}-\mathrm{H}_{2} \mathrm{O}\right]$ (55), 192 (85), 175 (75), 147 (90), 119 (100), $91\left[\mathrm{C}_{7} \mathrm{H}_{7}\right]$ (45).

\subsubsection{Indole-3-carboxylic acid (10)}

${ }^{1} \mathrm{H}$ NMR $\left(\mathrm{CD}_{3} \mathrm{OD}\right) \delta 8.05(1 \mathrm{H}, d d, \mathrm{~J}=8.0,1.1 \mathrm{~Hz}, 4-\mathrm{H})$, $7.94(1 \mathrm{H}, \mathrm{s}, 2-\mathrm{H}), 7.43(1 \mathrm{H}, d d, J=8.0,1.1 \mathrm{~Hz}, 7-\mathrm{H})$, $7.19(1 \mathrm{H}, d d d, J=8.0,8.0,1.1 \mathrm{~Hz}, 6-\mathrm{H}), 7.17(1 \mathrm{H}, d d d$, $J=8.0,8.0,1.1 \mathrm{~Hz}, 5-\mathrm{H})$. EI-MS $m / z$ (rel. int.) 161 $[\mathrm{M}]^{+} \bullet(100), 144[\mathrm{M}-\mathrm{OH}](77), 117\left[\mathrm{C}_{7} \mathrm{H}_{8} \mathrm{~N}\right](86), 91$ $\left[\mathrm{C}_{7} \mathrm{H}_{7}\right](47), 77\left[\mathrm{C}_{6} \mathrm{H}_{5}\right](12), 65\left[\mathrm{C}_{5} \mathrm{H}_{5}\right](25)$.

\subsubsection{Indole-3-carbaldehyde (11)}

ESI-MS $m / z$ (rel. int.) $146[\mathrm{M}+\mathrm{H}]^{+}$, daughter spectrum $(20 \mathrm{eV}) 146(31), 118[\mathrm{M}+\mathrm{H}-\mathrm{CO}](43), 117\left[\mathrm{C}_{7} \mathrm{H}_{8} \mathrm{~N}\right]$ (43), $91\left[\mathrm{C}_{7} \mathrm{H}_{7}\right](100), 65\left[\mathrm{C}_{5} \mathrm{H}_{5}\right](5)$.

\subsubsection{4-Methylbenzaldehyde (M)}

${ }^{1} \mathrm{H}$ NMR $\left(n\right.$-pentane- $\left.d_{12}\right) \delta 9.89(1 \mathrm{H}, s,-\mathrm{C} \underline{\mathrm{HO}}), 7.67$ $(2 \mathrm{H}, d, J=7.8 \mathrm{~Hz}, 2-\mathrm{H}$ and $6-\mathrm{H}), 7.21(2 \mathrm{H}, d, J=7.8 \mathrm{~Hz}$, $3-\mathrm{H}$ and 5-H), $2.36\left(3 \mathrm{H}, s, 4-\mathrm{CH}_{3}\right)$. ESI-MS $m / z$ (rel. int.) $121[\mathrm{M}+\mathrm{H}]^{+}$, daughter spectrum $(25 \mathrm{eV}) 93(5), 91(75)$,
77 (100), 65 (5), 51 (25). EI-MS $m / z$ (rel. int.) $120[\mathrm{M}]^{+}$. (100), $119[\mathrm{M}-\mathrm{H}](90), 91\left[\mathrm{C}_{7} \mathrm{H}_{7}\right](95), 65\left[\mathrm{C}_{5} \mathrm{H}_{5}\right](26)$. HREIMS $m / z 120.0570\left(\mathrm{C}_{8} \mathrm{H}_{8} \mathrm{O}\right.$, calc. 120.0575).

\section{Acknowledgements}

This work was jointly funded by the Max Planck Society, the Chinese Academy of Sciences, and Fonds der chemischen Industrie.

\section{References}

Abd El-Mawla, A.M.A., Beerhues, L., 2002. Benzoic acid biosynthesis in cell cultures of Hypericum androsaemum. Planta 214, 727-733.

Beimen, A., Bermpohl, A., Meletzus, D., Eichenlaub, R., Barz, W., 1992. Accumulation of phenolic compounds in leaves of tomato plants after infection with Clavibacter michiganense subsp. michiganense strains differing in virulence. Z. Naturforsch. 47c, 898-909.

Bennett, M., Gallagher, M., Fagg, J., Bestwick, C., Paul, T., Beale, M., Mansfield, J., 1996. The hypersensitive reaction, membrane damage and accumulation of autofluorescent phenolics in lettuce cells challenged by Bremia lactucae. Plant J. 9, 851-865.

Brader, G., Tas, E., Palva, E.T., 2001. Jasmonate-dependent induction of indole glucosinolates in Arabidopsis by culture filtrates of the nonspecific pathogen Erwinia carotovora. Plant Physiol. 126, 849-860.

Cvikrova, M., Nedelnik, J., Eder, J., Binarova, P., 1993. Changes in pattern of phenolic acids induced by culture filtrate of Fusarium oxysporum in alfalfa plants differing in susceptibility to the pathogen. J. Plant Physiol. 142, 1-5.

De Ascensao, A.R.F.D.C., Dubery, I.A., 2003. Soluble and wallbound phenolics and phenolic polymers in Musa acuminata roots exposed to elicitors from Fusarium oxysporum f.sp cubense. Phytochemistry $63,679-686$.

Dixon, R.A., 2001. Natural products and plant disease resistance. Nature 411, 843-847.

Dixon, R.A., Chen, F., Guo, D., Parvathi, K., 2001. The biosynthesis of monolignols: a 'metabolic grid', or independent pathways to guaiacyl and syringyl units? Phytochemistry 57, 1069-1084.

Ehlting, J., Büttner, D., Wang, Q., Douglas, C.J., Somssich, I.E., Kombrink, E., 1999. Three 4-coumarate:coenzyme A ligases in Arabidopsis thaliana represent two evolutionarily divergent classes in angiosperms. Plant J. 19, 9-20.

El Modafar, C., Tantaoui, A., El Boustani, E., 2000. Changes in cell wall-bound phenolic compounds and lignin in roots of date palm cultivars differing in susceptibility to Fusarium oxysporum f. sp. albedinis. J. Phytopathol. 148, 405-411.

Franke, R., Fry, S.C., Kauss, H., 1998. Low-molecular-weight precursors for defense-related cell wall hydroxycinnamoyl esters in elicited parsley suspension cultures. Plant Cell Rep. 17, 379-383.

Franke, R., Hemm, M.R., Denault, J.W., Ruegger, M.O., Humphreys, J.M., Chapple, C., 2002. Changes in secondary metabolism and deposition of an unusual lignin in the ref8 mutant of Arabidopsis. Plant J. 30, 47-59.

Fry, S.C., 1986. Cross-linking of matrix polymers in the growing cell walls of angiosperms. Annu. Rev. Plant Physiol 37, 165-186.

Hagemeier, J., Batz, O., Schmidt, J., Wray, V., Hahlbrock, K., Strack, D., 1999. Accumulation of phthalides in elicitor-treated cell suspension cultures of Petroselinum crispum. Phytochemistry 51, 629-635.

Hagemeier, J., Schneider, B., Oldham, N.J., Hahlbrock, K., 2001. Accumulation of soluble and wall-bound indolic metabolites in Arabidopsis thaliana leaves infected with virulent or avirulent Pseudomonas syringae pathovar tomato strains. Proc. Natl. Acad. Sci. U.S.A. $98,753-758$. 
Hahlbrock, K., Bednarek, P., Ciolkowski, I., Hamberger, B., Heise, A., Liedgens, H., Logemann, E., Nürnberger, T., Schmelzer, E., Somssich, I.E., Tan, J., 2003. Non-self recognition, transcriptional reprogramming, and secondary metabolite accumulation during plant/pathogen interactions. Proc. Natl. Acad. Sci. USA 10.1073/ pnas. 0831246100 .

Humphreys, J.M., Chapple, C., 2002. Rewriting the lignin road map. Curr. Opin. Plant Biol. 5, 224-229.

Iiyama, K., Lam, T.B.-T., Stone, B.A., 1994. Covalent cross-links in the cell wall. Plant Physiol. 104, 315-320.

Jarvis, A.P., Schaaf, O., Oldham, N.J., 2000. 3-Hydroxy-3-phenylpropanoic acid is an intermediate in the biosynthesis of benzoic acid and salicylic acid, but benzaldehyde is not. Planta 212, 119-126.

Kauss, H., Franke, R., Krause, K., Conrath, U., Jeblick, W., Grimmig, B., Matern, U., 1993. Conditioning of parsley (Petroselinum crispum L.) suspension cells increases elicitor-induced incorporation of cell wall phenolics. Plant Physiol. 102, 459-466.

Keller, H., Hohlfeld, H., Wray, V., Hahlbrock, K., Scheel, D., Strack, D., 1996. Changes in the accumulation of soluble and cell wallbound phenolics in elicitor-treated cell suspension cultures and fungus-infected leaves of Solanum tuberosum. Phytochemistry 42, 389-396.

Kombrink, E., Hahlbrock, K., 1986. Responses of cultured parsley cells to elicitors from phytopathogenic fungi. Timing and dose dependency of elicitor-induced reactions. Plant Physiol 81, 216-221.

Kovats, K., Binder, A., Hohl, H.R., 1991. Cytology of induced systemic resistance of tomato to Phytophthora infestans. Planta 183, 491-496.

Normanly, J., Bartel, B., 1999. Redundancy as a way of life-IAA metabolism. Curr. Opin. Plant Biol. 2, 207-213.

Nürnberger, T., Nennstiel, D., Jabs, T., Sacks, W.R., Hahlbrock, K.,
Scheel, D., 1994. High affinity binding of a fungal oligopeptide elicitor to parsley plasma membranes triggers multiple defense responses. Cell 78, 449-460.

Obel, N., Porchia, A.C., Scheller, H.V., 2003. Intracellular feruloylation of arabinoxylan in wheat: evidence for feruloyl-glucose as precursor. Planta 216, 620-629.

Reintanz, B., Lehnen, M., Reichelt, M., Gershenzon, J., Kowalczyk, M., Sandberg, G., Godde, M., Uhl, R., Palme, K., 2001. Bus, a bushy Arabidopsis CYP79F1 knockout mutant with abolished synthesis of short-chain aliphatic glucosinolates. Plant Cell 13, 351367.

Somssich, I.E., Hahlbrock, K., 1998. Pathogen defence in plants - a paradigm of biological complexity. Trends Plant Sci. 3, 86-90.

Tiburzy, R., Reisener, H.J., 1990. Resistance of wheat to Puccinia graminis f. sp. tritici: association of the hypersensitive reaction with the cellular accumulation of lignin-like material and callose. Physiol. Mol. Plant Pathol. 36, 109-120.

Tsuji, J., Jackson, E.P., Gage, D.A., Hammerschmidt, R., Sommerville, S.C., 1992. Phytoalexin accumulation in Arabidopsis thaliana during the hypersensitive reaction to Pseudomonas syringae pv syringae. Plant Physiol. 98, 1304-1309.

Tsuji, J., Zook, M., Sommerville, S.C., Last, R.L., Hammerschmidt, R., 1993. Evidence that tryptophan is not a direct biosynthetic intermediate of camalexin in Arabidopsis thaliana. Physiol. Mol. Plant Pathol. 43, 221-229.

Wildermuth, M.C., Dewdney, J., Wu, G., Ausubel, F.M., 2001. Isochorismate synthase is required to synthesize salicylic acid for plant defence. Nature 414, 562-565.

Zhao, J.M., Last, R.L., 1996. Coordinate regulation of the tryptophan biosynthetic pathway and indolic phytoalexin accumulation in Arabidopsis. Plant Cell 8, 2235-2244. 